\title{
Acceleration of Azidation by Microwave Irradiation
}

\author{
Sang Hyun Park \\ Diwision of Isotope Application, Korea Atomic Energy Research Institute, 150 Deokin-dong, \\ Itseong-gt, Daejeon 305-353, Korea \\ Received June 27, 2002
}

Key Words : Microwave assisted reaction. Acceleration of azidation. Microwave assisted azidation. Synthesis of alkyl azides

Azides are versatile intermediates in organic synthesis. since they can be used for the preparation of a variety of amines or amino compounds that show interesting biological activities. $^{1-5}$ As simpler, milder and more efficient methods for the reduction of azides to amines have been developed. 5,6 azides have recently been drawing much attention in synthetic organic chemistry. In the context of our recent studies. it has also been shown that $\beta$-amino acids can be prepared from indium--mediated reduction of the corresponding azides that are transformed chemically from microbial polymer polyhydrosyalkanoates (PHAs). ${ }^{7}$ In connection with our ongoing research project for the synthesis of biologically active modified peptides containing $\beta$-amino acids. ${ }^{s}$ we require a simple and fast preparation of azides which can serve for reductive process resulting in amines or amino compounds.

We describe use of microwave to promote a reaction of tosylates with azide ion. Many reactions have been accelerated by the use of microwave, ${ }^{9}$ but application to azide introduction represents a particular useful transformation. Although considered a good nucleophile, azides often react very slowly with many halides and other alkylating agents. Such reactions cannot usually be heated since the product azides frequently decompose or have the hazardous nature in general. ${ }^{1}$ Thus the microwave assisted process will be of interest to many chemists who work with azides.

In this paper, we report a novel, simple and efficient method for the preparation of azides using a microwave technique which has been employed to reduce pollution at the source and to increase atom economy. ${ }^{10}$

Synthesis of optically active ethyl 3-azidobutyrates. Ethyl (S)-(+)-3-azidobutyrate (1) and ethyl $(R)-(-)$-3-azidobutyrate (2) were prepared by stirring of the corresponding tosylates with sodium azide at room temperature for $12 \mathrm{~h}$ (Scheme 1). ${ }^{7}$ It should be noted that no conventional heating under reflux was employed in order to effect this reaction with the desired configuration at the chiral center. Transposition of this procedure to a domestic microwave oven led to a huge reduction of the reaction time $(5 \mathrm{~min})$ in similar yield with desired configurations (Table 1). The very rapid rise of temperature of reactants via microwave irradiation favors some reaction pathways over others and thus leads to

"Corresponding author: Phone: $+82-42-868-8514$ : Fax: $+82-42-$ 868-8448; e-mail: parkshakaeri.re.kr

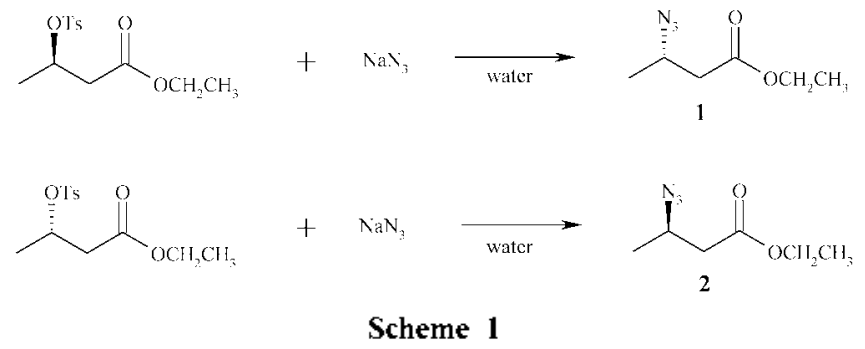

Table 1. Results on the preparation of optically active ethyl 3azidobutyrates ( 1 and 2)

\begin{tabular}{ccccccc}
\hline \multirow{2}{*}{ Product } & \multicolumn{3}{c}{ Conventional method } & \multicolumn{3}{c}{ Microwave inadiation } \\
\cline { 2 - 7 } & Time & Yield & {$[\alpha]_{\mathrm{I}}{ }^{a}$} & Time & Yield & {$[\alpha]_{\mathrm{D}}{ }^{\circ}$} \\
\hline 1 & $12 \mathrm{~h}$ & $76 \%$ & $+41^{\circ}$ & $5 \mathrm{~min}$ & $78 \%$ & $+42^{\circ}$ \\
2 & $12 \mathrm{~h}$ & $78 \%$ & $-35^{\circ}$ & $5 \mathrm{~min}$ & $82 \%$ & $-35^{\circ}$ \\
\hline
\end{tabular}

a(c l, $\left.\mathrm{CHCl}_{3}\right)$.

selectivity and hence cleaner products. ${ }^{9 d}$

Synthesis of alkyl azides. Cyclohexyl azide (3) was prepared by the heating of the corresponding tosylate with sodium azide in $N, N$-dimethylformamide (DMF) at $90{ }^{\circ} \mathrm{C}$ for $12 \mathrm{~h}$ (Scheme 2). ${ }^{7}$ Transposition of this procedure to a domestic microvave oven led to a huge reduction of the reaction time (3 $\mathrm{min}$ ) in a similar yield $(91 \%$ ) (Table 2). A simple conical flask with a loose cover was used as a reaction vessel, and no stirrer was used since the reactants

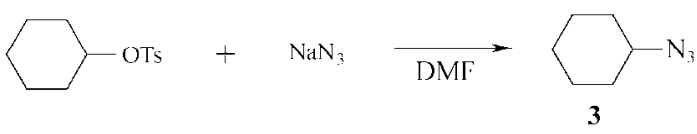

Scheme 2

Table 2. Results on the preparation of alkyl azides 3 and $\mathbf{4}$

\begin{tabular}{ccccccc}
\hline \multirow{2}{*}{ Product } & \multicolumn{2}{c}{ Conventional heating } & \multicolumn{3}{c}{ Microwave irradiation } \\
\cline { 2 - 6 } & Time & Temp. & Yield & Time $^{\prime}$ & Temp. & Yield \\
\hline 3 & $12 \mathrm{~h}$ & $90^{\circ} \mathrm{C}$ & $91 \%$ & $5 \mathrm{~min}$ & $90^{\circ} \mathrm{C}$ & $92 \%$ \\
4 & $12 \mathrm{~h}$ & $90^{\circ} \mathrm{C}$ & $92 \%$ & $5 \mathrm{~min}$ & $90^{\circ} \mathrm{C}$ & $94 \%$ \\
\hline
\end{tabular}

The progress of reaction was monitored by the thin layer chromatography every minute. "The approximate temperature of the reaction mixture was determined by using a themometer immediately after the microvave irradiation was stopped. and the temperature of the reaction mixture was controlled by a beaker of water as a heat sink. ${ }^{9 d}$ 


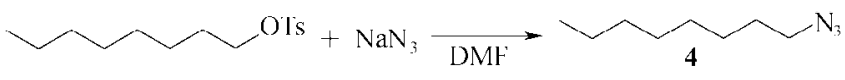

Scheme 3

are energized directly due to the characteristic heating properties of microwave. Since DMF has a reasonably high boiling point $\left(153^{\circ} \mathrm{C}\right)$ and a substantial dipole resulting in absorption of microwave. it was used as the reaction medium as in conventional heating. Octyl azide (4) was also prepared in DMF by both conventional heating and microwave irradiation (Scheme 3). and the results are summarized in Table 2 .

In summary. we have developed a novel, simple and efficient method for the small- scale preparation of azides for laboratory use in which tosylates were treated with sodium azide in water or DMF under microwave irradiation to afford the corresponding azides 1-4 in quantitative yields. The results obtained with azides demonstrated the generality of the reaction. This methodology is expected to be applicable to the simple and efficient preparation of amines or anino compounds from the corresponding alcohols or hydroxy compounds via rapid nicrowave assisted synthesis of azides. Currently. we are in the process of using this method for the preparation of $\beta$-anino acids from diverse members of microbial polyester $\mathrm{PHAs}^{11}$ as a chiral pool. the results of which will be reported in due course.

\section{Experimental Section}

Flash colunu chromatography was performed on silica gel 60 (230-400 mesh, Merck) and all chromatographic separations were monitored by TLC analyses. performed using glass plates precoated with $0.25-\mathrm{mm}, 230-400$ mesh silica gel intpregnated with a fluorescent indicator $(254 \mathrm{~nm})$. Optical rotations were measured on a JASCO DIP-181 Digital Polarimeter. IR spectra were recorded on a Bomen MBl54 FTIR (KBr pellets or neat). ${ }^{1} \mathrm{H}$ NMR and ${ }^{13} \mathrm{C}$ NMR were recorded on a Bruker $500-\mathrm{MHz}$ FTNMR spectrometer in $\mathrm{CDCl}_{3}, \mathrm{DMSO}_{6}$. or $\mathrm{D}_{3} \mathrm{O}$ solution. and chemical shifts were recorded in ppm units using $\mathrm{SiMe}_{4}$ as an internal standard. Mass spectra were measured on a Varian MAT 371 Mass Spectrometer at $70 \mathrm{eV}$

\section{Preparation of Ethyl (S)-(+)-3-azidobutyrate (1).}

Conventional method ${ }^{7}$ : Reaction mixture of tosylate ( 854 mg. $2.98 \mathrm{mmol}$ ). hexadecyltributylphosphonium bromide (150 mg. $0.30 \mathrm{mmol}$ ) and sodium azide (387 mg. 5.96 mmol) in water $(2.5 \mathrm{~mL})$ was vigorously stirred at room temperature. After $12 \mathrm{~h}$. ether $(20 \mathrm{~mL})$ was added and the organic laỵer was collected and dried over sodium sulfate. Evaporation under reduced pressure gave $355 \mathrm{mg}(76 \%)$ of the title compound as a light-yellow oil: $[\alpha]_{D}+41^{\circ}(c) 1$. $\mathrm{CHCl}_{3}$ ): IR (neat) 2982, 2936, 2122, 1742, 1377, 1295. 1254.1185. $1028 \mathrm{~cm}^{-1}$ : 'H NMR $\left(\mathrm{CDCl}_{3}\right) \delta 1.27$ (q. $J=7.0$ $\left.\mathrm{Hz}, 3 \mathrm{H}, \mathrm{OCH}_{2} \mathrm{CH}_{3}\right) .1 .34\left(\mathrm{~d} J=6.5 \mathrm{~Hz}, 3 \mathrm{H}, \mathrm{CH}_{3} \mathrm{CH}\left(\mathrm{N}_{3}\right)\right)$. $3.95-4.04\left(\mathrm{~m}, 1 \mathrm{H}, \mathrm{CHN}_{3}\right), 4.18\left(\mathrm{q}, J=7.0 \mathrm{~Hz}, 2 \mathrm{H}, \mathrm{OCH}_{2}\right)$ : ${ }^{13} \mathrm{C}$ NMR $\left(\mathrm{CDCl}_{3}\right) \delta 14.17,19.51,41.17,54.34,60.87$.
170.56; CIMS, $m z 157\left(\mathrm{M}^{+}\right) .155 .149 .131 .115 .91$ (base), $88,84,73.70 .69 .60 .57,56,55,49$.

Microwcre method: Reaction mixture of tosylate $(854 \mathrm{mg}$. $2.98 \mathrm{mmol}$ ), hexadecyltributylphosphonium bronide (150 $\mathrm{mg}, 0.298 \mathrm{mmol}$ ) and sodium azide (387 $\mathrm{mg}, 5.96 \mathrm{mmol}$ ) in water $(5 \mathrm{~mL})$ was irradiated in a domestic microwave oven at an output of 1000 watts for $5 \mathrm{~min}$. The progress of azidation was monitored by TLC analysis every minute. Water $(100 \mathrm{~mL})$ was placed in another vessel and irradiated simultaneously. After cooling to room temperature. ether ( 20 $\mathrm{mL}$ ) was added and the organic layer was collected and dried over sodium sulfate. Evaporation under reduced pressure gave $365 \mathrm{mg}(78 \%)$ of the title compound as a light-yellow oil: $\left.[\alpha]_{\mathrm{D}}+42^{\circ}(c) \mathrm{l}, \mathrm{CHCl}_{3}\right)$; IR (neat) 2982, 2936, 2122 , 1745. 1377, 1295. 1254, $1185,1028 \mathrm{~cm}^{-1},{ }^{1} \mathrm{H} \mathrm{NMR}\left(\mathrm{CDCl}_{3}\right)$ $\delta 1.27\left(\mathrm{q}, J=7.0 \mathrm{~Hz}, 3 \mathrm{H}, \mathrm{OCH}_{2} \mathrm{CH}_{3}\right), 1.34(\mathrm{~d}, J=6.5 \mathrm{~Hz}$, $\left.3 \mathrm{H} . \mathrm{CH}_{3} \mathrm{CH}\left(\mathrm{N}_{3}\right)\right), 3.95-4.04\left(\mathrm{~m} . \mathrm{H} . \mathrm{CHN}_{3}\right), 4.18(\mathrm{q} . J=7.0$ Hz. $\left.2 \mathrm{H}, \mathrm{OCH}_{2}\right),{ }^{13} \mathrm{C}$ NMR $\left(\mathrm{CDCl}_{3}\right) \delta 14.2 .19 .5 .41 .2,54.3$, 60.9. 170.6; CIMS, $m z 157\left(\mathrm{M}^{+}\right) .155,149.131 .115,91$ (base). 88. 84. 73. 70.69.60.57. 56.55.49.

Preparation of Ethyl ( $R$ )-(-)-3-azidobutyrate (2) Same as 1 except for the opposite sign of the specific rotation: $[\alpha]_{D}$ $-35^{\circ}\left(\mathrm{c} 1 . \mathrm{CHCl}_{3}\right)$.

\section{Preparation of Cyclohexyl azide (3)}

Comentional method?: Reaction mixture of tosylate (765 $\mathrm{mg} .3 .00 \mathrm{mmol}$ ) and sodium azide (390 $\mathrm{mg} .6 .00 \mathrm{mmol}$ ) in DMF $(5.0 \mathrm{~mL})$ was heated at $90^{\circ} \mathrm{C}$ for $12 \mathrm{~h}$. After cooling to room temperature. ether $(20 \mathrm{~mL})$ was added and the organic layer was washed with water. collected and dried over sodium sulfate. Evaporation under reduced pressure and flash columm chromatography gave $341 \mathrm{mg}(91 \%)$ of the title compound as a light-yellow oil.

Microwine method: Reaction mixture of tosylate $(765 \mathrm{mg}$. $3.00 \mathrm{mmol}$ ) and sodium azide ( $390 \mathrm{mg}, 6.00 \mathrm{mmol}$ ) in DMF $(5.0 \mathrm{~mL})$ was irradiated in a domestic microwave oven at an output of 1000 watts for $5 \mathrm{~min}$. The progress of azidation was monitored by TLC analysis every minute. Water (100 $\mathrm{mL}$ ) was placed in another vessel and irradiated simultaneously: After cooling to room temperature ether ( 20 $\mathrm{mL}$ ) was added and the organic layer was collected, washed with water and dried over sodium sulfate. Evaporation under reduced pressure and flash column chromatography gave $345 \mathrm{mg}(92 \%)$ of the title compound as a light-yellow oil: IR (neat) $3116,2306,2097 \mathrm{~cm}^{-1}$ : ${ }^{l} \mathrm{H}$ NMR (500 MHz. CDCl $)$ $\delta 1.15-1.45(\mathrm{~m}, 5 \mathrm{H}), 1.60-1.65(\mathrm{~m}, 1 \mathrm{H}), 1.70-1.82(\mathrm{~m}, 2 \mathrm{H})$. $1.85-1.95(\mathrm{~m}, 2 \mathrm{H}), 3.34\left(\mathrm{~m}, 1 \mathrm{H}, \mathrm{N}_{2} \mathrm{CH}\right):{ }^{13} \mathrm{C}$ NMR $(500$ $\left.\mathrm{MHz}, \mathrm{CDCl}_{2}\right) \delta 24.3,25.3 .31 .6 .59 .9$ : CIMS. $m z 125\left(\mathrm{M}^{-}\right)$. $68,55,49$ (base). 54, 40, 26.

Preparation of Octyl azide (4): IR (nujol) 2955, 2900. 2845. 2310, 2090. 1465. $1375 \mathrm{~cm}^{-1}$ : 'H NMR $\left(\mathrm{CDCl}_{3}\right) \delta$ 0.93 (t. $\left.J=7.1 \mathrm{~Hz}, 3 \mathrm{H}, \mathrm{CH}_{3}\right), 1.12-1.82(\mathrm{~m}, 12 \mathrm{H}) .3 .49(\mathrm{t} . J$ $\left.=6.5 \mathrm{~Hz}, 2 \mathrm{H}, \mathrm{CH}_{2} \mathrm{~N}_{3}\right):{ }^{13} \mathrm{C}$ NMR $\left(\mathrm{CDCl}_{2}\right) \delta 28.6,29.9 .31 .2$. 51.2: CIMS, me $155\left(\mathrm{M}^{-}\right), 113,85.71,57.43$ (base), 41. 29

Acknowledgement. This work was supported by the Korea Ministry of Science and Teclunolog: 


\section{References}

1. Sheradsky, T. In Chemishy of the Azido Group: Patai. S., Ed.: Inter Science: New York. 1971: p 331.

2. Kabalka. G. W.: Li. G. Tetrahedron Lett. 1997. 38. 5777.

3. Kamal. A.: Arifuddin. M.: Rao. M. V. Tetrahedron Astmmetry $1999,10,4261$

4. Schildknegt, K.: Agrios. K. A.: Jeftrey, A. Tetratredron Lett. 1998. 39.7687 .

5. Butcher. J. W.: Liverton. N. J.: Selnick. H. G.: Elliot. J. M.: Smith. G. R.: Tebben. A. J.: Pribush. D. A.: Wai. J. S.: Claremon. D. A. Tetrahedron Lett. 1996, 37, 6685.

6. Reddy. G. V.: Rao. G. V: Iyengar. D. S. Tetrahedron Lett. 1999. 40,3937 .
7. Park, S. H.: Lee, S. H.: Lee, S. Y. J. Chem. Research (S) 2001 2001.498 .

8. Gademann. K.: Ernst. M.: Hoyer. D.: Seebach. D. Heh: Chint Acta 2000. 83. 16.

9. For recent overviews on microwave assisted chemistry. see: (a) Vanna. R. S. Green Chem. 1999. 1. 43. (b) Bose A. K.: Banik. B. K: Laylinstaia. N.: Jayaraman. M; Manhas. M. S. Chemtech. 1997. 27. 18. (c) Majetich. G.: Hichs. R. I. Hicomowe Powe? Electontagn. Energy 1995. 30. 27. (d) Manhas. M. S.: Banik. B K.: Mathur. A.: Vincent. T. E.: Bose. A. K. Tetrahedron 2000. 56. 5587. (e) Bose, A. K.; Banik, B. K; Mathur. C: Wagle, D. R.: Manhas. M. S. Tetrahedron 2000. 56. 5603.

10. Trost. B. M. Science 1991, 254. 1471.

11. Lee. S. Y. Biotechol Biong 1996. 49. 1. 